\title{
Application of RELUX Software in Simulation and Analysis of Energy Efficient Lighting Scheme
}

\author{
Shailesh $\mathrm{K} \mathrm{R}$ \\ Senior Lecturer \\ Department of $E$ \& E Engineering \\ MIT, Manipal University - 576104, India
}

\author{
Tanuja S Raikar \\ Lecturer \\ Department of Computer Science Engineering \\ MIT, Manipal University - 576104, India
}

\begin{abstract}
Designing a building with maximum utilization of daylight and use of energy efficient luminaires will reduce the cost of energy use. In the present study, by means of computer simulations using RELUX software, the interaction between natural and artificial light and the related illumination conditions expected in a commercial office building in Mumbai, India have been simulated and analysed. In this way, it was possible to evaluate the relevant loads for artificial illumination that has been considered not as the principal but a complementary light source. The main goal of this study is to show the potential of drastically reducing the electrical energy consumptions for illumination, by adopting day lighting harvesting solutions. Comparison were done using two different lighting schemes one with Fluorescent Luminaires and without daylight harvesting and other one with LED fixtures with daylight harvesting using combined occupancy and daylight dimming sensors. With the latter scheme a saving of $80 \%$ can be achieved on energy and operating costs for a period over 25 years.
\end{abstract}

\section{General Terms}

Computer Aided Design, RELUX Simulation

\section{Keywords:}

Day light; Lighting control; Occupancy sensor; Computer simulation; Relux;

\section{INTRODUCTION}

The construction sector in India is witnessing a fast growth due to increased demand for housing, strong demographic impetus, expansion of organized retail, increased demand for commercial office spaces by multinationals and IT (information technology) hubs, and coming up of SEZs (special economic zones). Most Indian buildings are also copying western energy-intensive building concepts such as high air-conditioning and heat radiating glass. Making Indian buildings energy efficient is thus crucial. In the most commercial offices in India, artificial light is the main contributor to the visual environment, even though there is an abundance of daylight and the working hours in offices utilise much of the daylight hours. Strategies for more daylight inclusion is needed for office interiors in context of any city which has a growing demand on electricity, far in excess of its production.
Integrated artificial and daylight harvesting schemes with energyefficient luminaires and lighting controls can help reduce the electrical demand and improve vision efficiency of the building occupants [1, 2]. Proper daylight-linked lighting controls have a strong potential for reducing building electricity use. As daylight produces less heat per unit of illumination than many artificial lighting systems, day lighting may reduce cooling requirements when it replaces artificial lighting [3-5]. Heat gain and heat loss through windows, glare control, and variations in daylight availability must be carefully balanced. Recently, strong recognition has been given to the contribution that daylight can make to energy conservation in buildings [6-8]. A number of design strategies can be applied in new buildings and in the retrofit of existing buildings. Field measurements on commercial buildings using daylight-linked light controls revealed that the annual lighting energy can be saved by $30-60 \%$ of total electric lighting consumption $[9,10]$. The energy savings derived through the use of day lighting not only facilitate the sparing use of electric lighting and reduced peak electrical demand, but also reduce cooling loads and offer the potential for smaller airconditioning plants to be built $[11,12]$. The determinations of daylight illuminance and lighting energy savings can be performed computer simulations [13] or simple calculation methods [14]. Daylight helps reduce the electricity use for electrical lighting. Also, because of the high luminous efficacy, less heat will be dissipated for the same lighting requirement and, hence, there will be less demand for cooling. This is particularly beneficial to tropical and subtropical regions. In tropical Mumbai, air-conditioning and lighting account for over two-thirds of total electricity use for typical non-residential buildings [downloaded paper]. It is not difficult to understand that day lighting controls can result in significant energy savings.

This paper highlights the importance of proper integration of artificial and day lighting schemes in saving energy costs in a commercial building in Mumbai. Computational analysis using RELUX software has helped to evaluate the performance of the integrated artificial-day lighting scheme in the office building over a period of one year. The study showed that day lighting measures are only efficient when the performance of artificial lighting systems is also addressed with new efficient lamps and luminaries and an advanced control system are installed. The paper aims at providing building professionals, practitioners and researchers more information and a better understanding of daylight-artificial light integrated schemes for promoting effective day lighting designs. 


\section{CASE STUDY}

The commercial building chosen for the case study is just five minutes walking distance from Ghatkopar (W) railway station in Mumbai. The seven storey building exclusively is being made for business class offering shops on the ground floor and one office per floor for the rest of the seven floors. The complex also provides modern facilities such as multiple cars parking in basement, two high speed elevators.

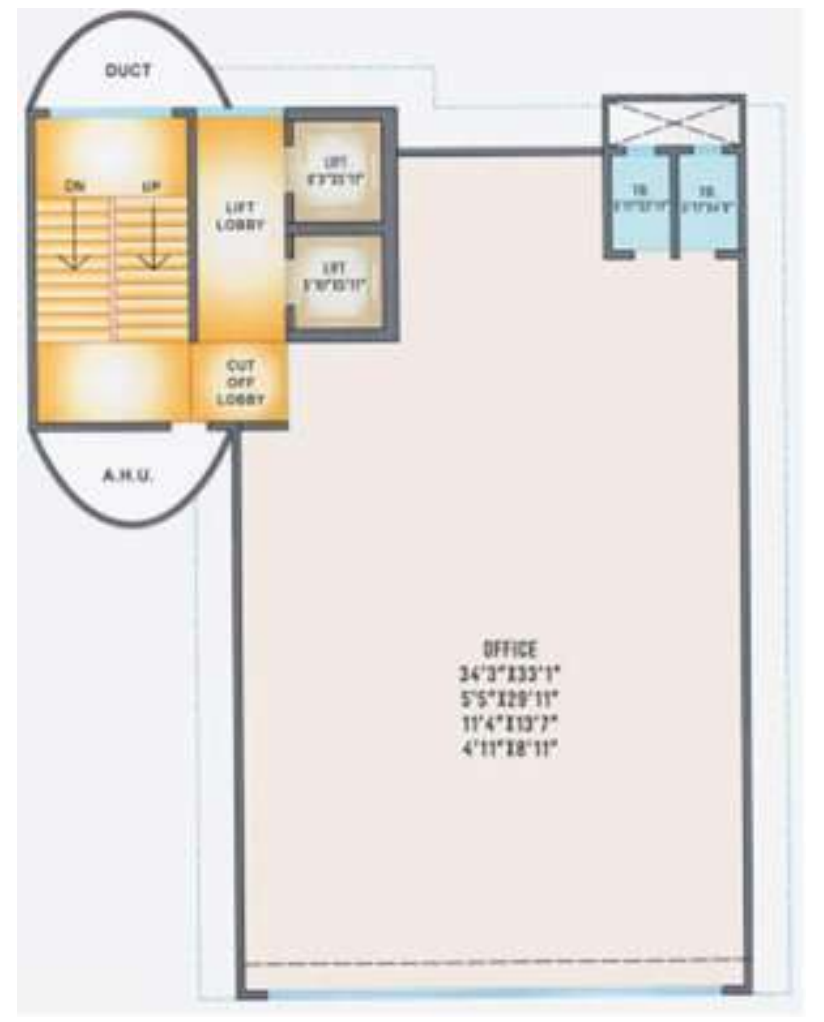

Figure 1. Floor plan of the office used for study

The building chosen for study is still under construction. The purpose of choosing this still under-construction building is to allow implementing the modifications pointed out during the study in the final ready to occupy building. The building is a RCC framed earthquake resistant structure with aesthetically designed appealing elevation with quality structural glazing. The structural glazing of type SGG ANTELIO PLUS (Blue Ray ST 767) [15] will supply by Saint Gobain India. The suggested existing glazing is reflective solar control exterior glass that will be used in the building to block the incoming heat radiation from the sun, while allowing in natural light. The characteristics of the existing (as planned by the builder) and proposed (as suggested by the authors) glazing are compared in the Table 1 .

The building has seven office floors. As per the existing design proposed by the builder, all the office floors will be illuminated by $2 \times 2$ nine cell parabolic troffer [16] housing three $40 \mathrm{~W}$ TT5 lamps of GE make. The luminous intensity diagram and fixture photograph are shown in Figure 2. As per existing plan the building will rely on artificial lighting during the office hours from $09: 00 \mathrm{hrs}$ to $18: 00 \mathrm{hrs}$. The building has structural glazing along the Eastern side as seen in Figure 1. All other walls of the building are made of concrete. Building has no obstruction for at least 100 metres from the Eastern side. Day light can be harvested only along the Eastern side.

Table 1. Comparison of structural glazing characteristics

\begin{tabular}{|l|c|c|}
\hline \multicolumn{1}{|c|}{ Property } & Existing & Proposed \\
\hline Type & $\begin{array}{c}\text { SGG ANTELIO PLUS } \\
\text { (Blue Ray ST 767) }\end{array}$ & $\begin{array}{c}\text { SGG ANTELIO } \\
\text { PLUS (Emerald Glaze } \\
\text { ST 467) }\end{array}$ \\
\hline Light Transmittance & 0.39 & 0.47 \\
\hline Solar Factor & 0.37 & 0.31 \\
\hline Shading Co-efficient & 0.43 & 0.35 \\
\hline $\begin{array}{l}\text { Relative Heat Gain } \\
\text { (Ashrae Value) }\end{array}$ & $306 \mathrm{~W} / \mathrm{m}^{2}$ & $253 \mathrm{~W} / \mathrm{m}^{2}$ \\
\hline U-Value & $2.8 \mathrm{~W} / \mathrm{m}^{2} \mathrm{~K}$ & $1.77 \mathrm{~W} / \mathrm{m}^{2} \mathrm{~K}$ \\
\hline
\end{tabular}

The building owners never planned to use daylight harvesting for illuminating the office interiors. So authors felt that by taking up this case study and with the help of RELUX software they could bring out the advantages of daylight harvesting and its impact on energy costs. Authors also wanted to highlight the impact of choosing energy efficient light sources and proper glazing for effective daylight harvesting and reducing operating costs. The analysis made by the authors could help in convincing the builders for changing the fixtures and glazing at an early stage and go with the recommendations made by the authors.

\section{ARTIFICIAL ILLUMINATION}

This section deals with detailed RELUX software analysis of artificial lighting schemes considering both existing Fluorescent and proposed LED luminaires. It is assumed that the offices are lit by artificial light sources throughout the office hours without making use of daylight harvesting. The working service illuminance is considered to be 500 lux as per Indian Standards [17] and number of working hours considered is 2088 hours for the entire year.

\subsection{Existing Illumination Scheme}

The existing lighting scheme is provided by Parabolic Troffers housing three GE made 40W Single Ended Twin Fluorescent tubes. The scheme is designed for a service illuminance of 500 lux as per Indian Standard IS-3646I:1992 [17] assuming a maintenance factor of 0.8 using RELUX software. Computer simulation of the existing lighting levels in the office floors are obtained using RELUX software and shown in Figure $3 \mathrm{a}$ and illuminance results are summarised in Table 2. The current scenario is to use artificial illumination throughout the working hours for interior illumination. If interior illumination is provided by the existing Fluorescent luminaires throughout the day, the annual energy costs would be around Rs 160,000 at a power tariff of Rs 6 per KWH. Mumbai is a tropical city and lot of daylight is available throughout the day and major portion of the year as seen from RELUX simulations in Figure 4. The simulations show when artificial light is required and when daylight alone can provide necessary interior illuminance. During the annual operations of the building offices around $96 \%$ 
(around 2002 hours of 2088 working hours) of the time daylight alone can provide sufficient working illuminance and only $4 \%$ of the time the offices require artificial illuminance. If we go by this observation then Fluorescent luminaires have to be operated only for 86 hours there by resulting in an annual operating cost of Rs 6,400 thereby saving Rs 153,600 . It is assumed that daylight will provide the required illuminance throughout the office interiors,
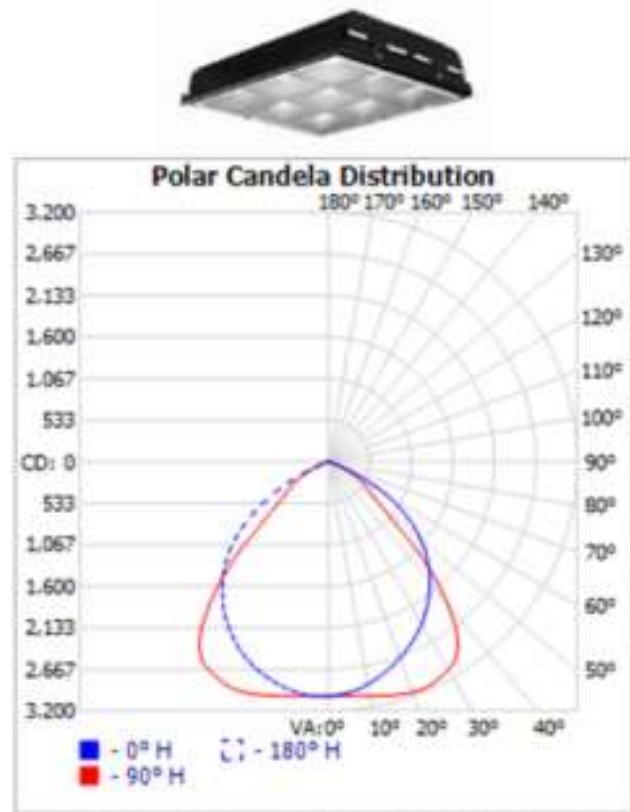

Luminaire 1-2×2 NINE CELLPARABOLIC TROFFER HOUSING THREE 40-WATT SINGLE ENDED TWIN TUBE FLUORESCENTS (EVISTING L.UMINAIRE) but in reality this is not the case as seen from Figures 5 and 6 . There is a requirement of artificial illumination even during day hours. Due to the building orientation and dimensions of the offices not all portions of the offices are illuminated to the desired daylight factor of 5\% [6]. Hence the best way to provide service illuminance is to integrate both artificial and daylight schemes with daylight dependent lighting control system.
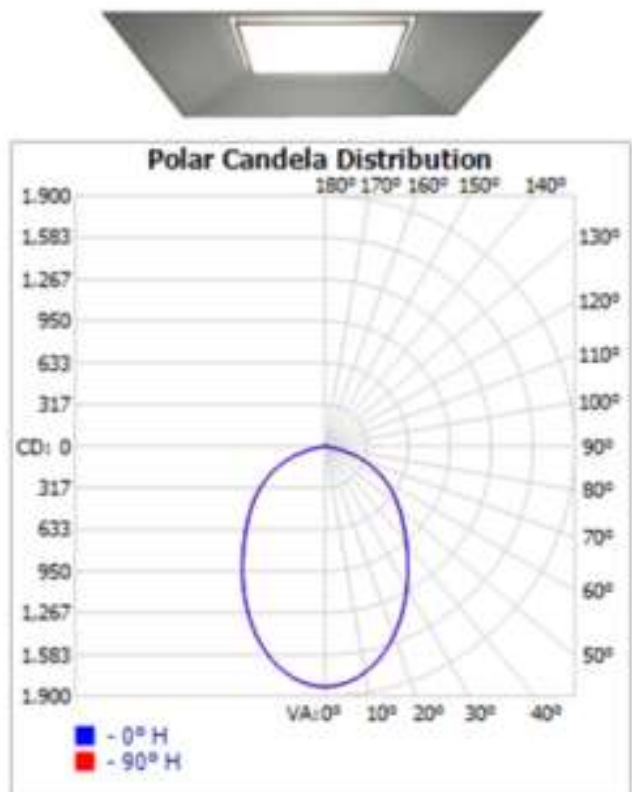

Luminaire 2-2×2 ARCHITECTURAL LAY-IN TROFFER (RECOMMENDED LUMINAIRE)

Figure 2. Luminaires - existing fluorescent luminaire (Luminaire 1) and suggested LED luminaire (Luminaire 2) for the building

Table 2. Results overview

\begin{tabular}{|l|r|r|}
\hline \multicolumn{1}{|c|}{ Details } & Fluorescent Luminaire & LED luminaire \\
\hline Number of Luminaires required in each office floor & 14 & 27 \\
\hline Wattage Per Luminaire (Watts) & 130 & 52 \\
\hline Average Illuminance (LUX) - $\mathrm{E}_{\mathrm{AVE}}$ & 538 & 535 \\
\hline Minimum Illuminance (LUX) - $\mathrm{E}_{\mathrm{MIN}}$ & 271 & 343 \\
\hline Maximum Illuminance (LUX) - $\mathrm{E}_{\mathrm{MAX}}$ & 660 & 621 \\
\hline Uniformity Ratio - $\mathrm{E}_{\mathrm{MIN}} / \mathrm{E}_{\mathrm{AVE}}$ & 0.50 & 0.64 \\
\hline Uniformity Ratio - $\mathrm{E}_{\mathrm{MIN}} / \mathrm{E}_{\mathrm{MAX}}$ & 0.41 & 0.55 \\
\hline Total Luminous Flux of all luminaires (Klum) for all seven office floors & 926 & 719 \\
\hline Total Power (Kilo Watts) for all seven office floors & 12.74 & 9.82 \\
\hline Annual Energy Costs (approximate) & Rs 160,000 & Rs 120,000 \\
\hline
\end{tabular}




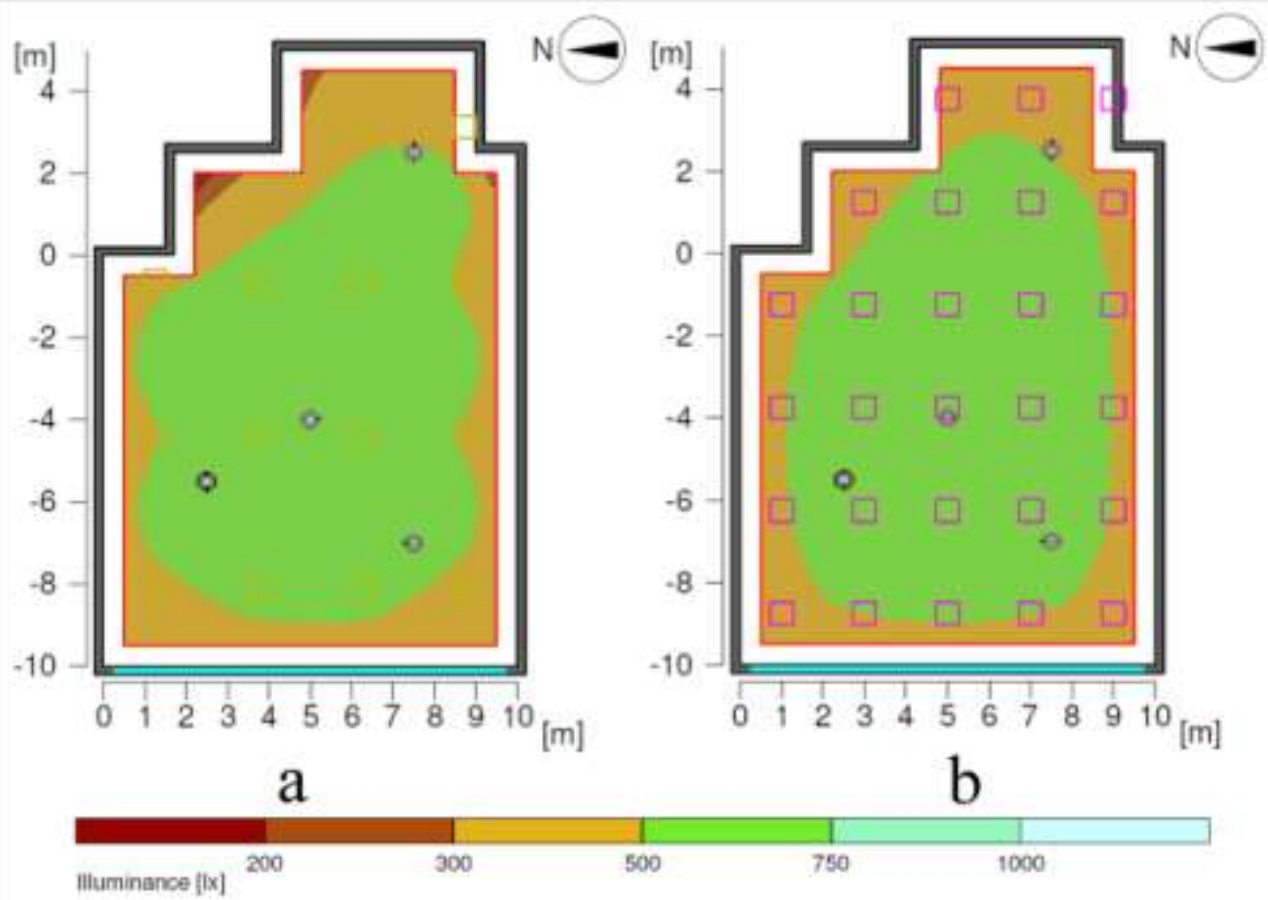

Figure 3. Lighting levels for the office floors with existing fluorescent luminaires (a) and proposed LED luminaires (b)

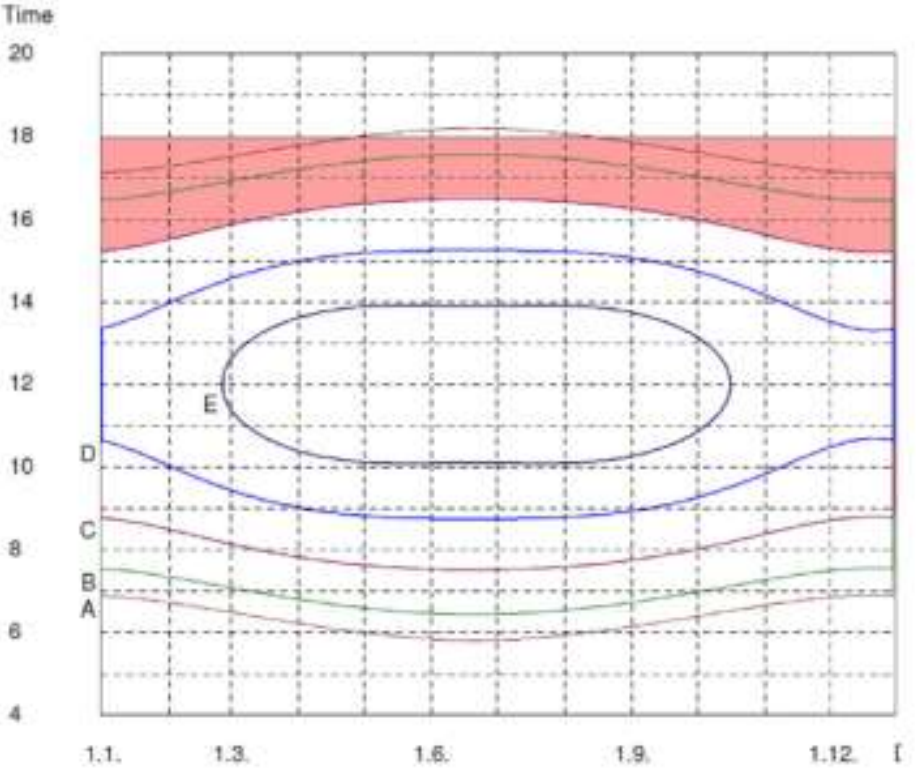

a - CIE Overcast Sky

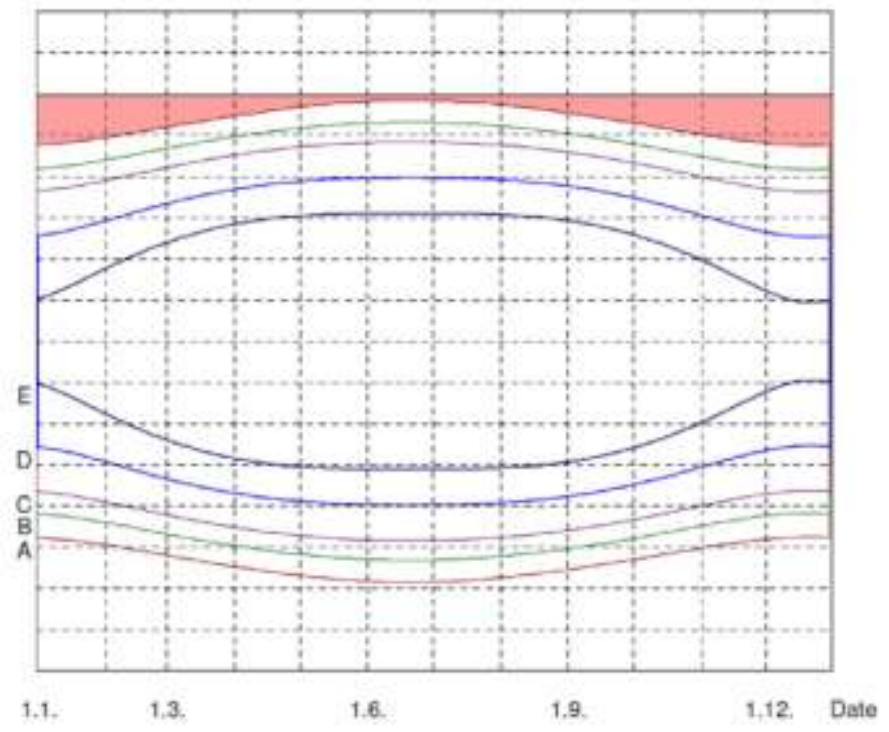

b - CIE Clear Sky

Antifcial light necessary

Figure 4. Exterior Illuminance isolux curves 


\section{For CIE Overcast Sky}

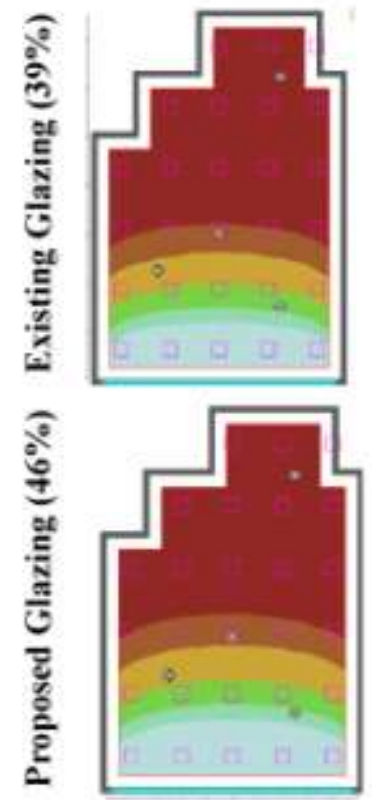

a) 11:00AM, 23 June
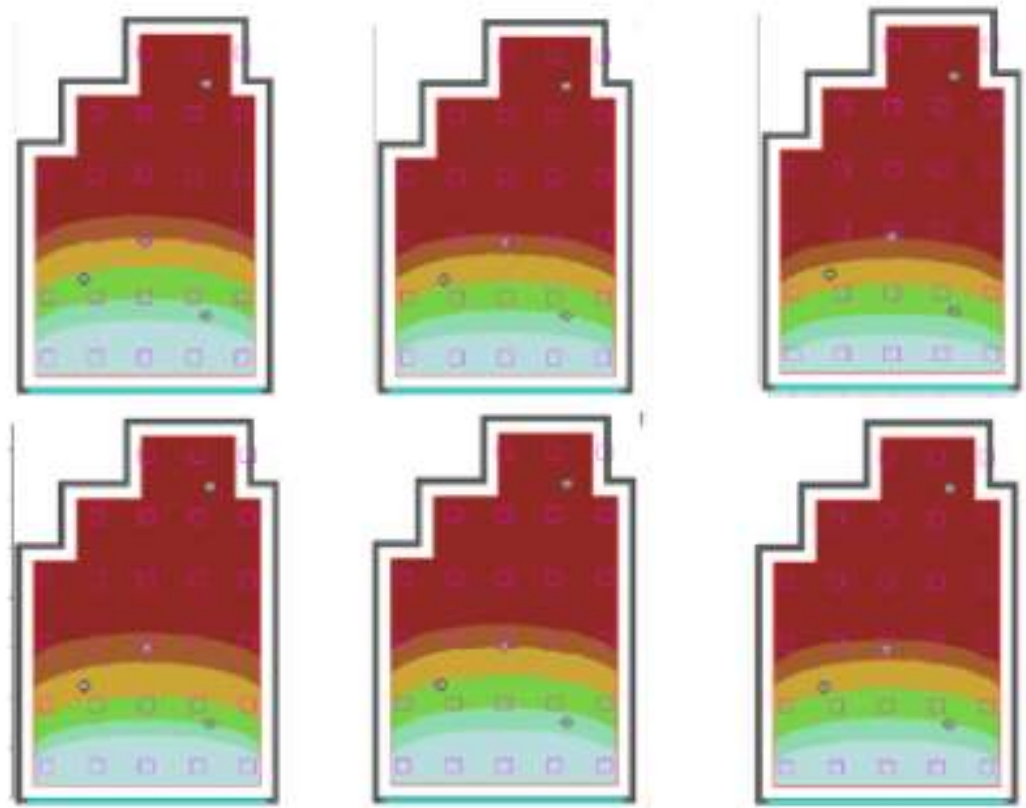

b) 03:00PM, 23 June

c) 11:00AM, $22 \mathrm{Dec}$

d) 03:00PM, $22 \mathrm{Dec}$

Illuminance $[\mathrm{lx}]$

100

150

200

300

500

Figure 5. Illuminance levels in the office interior due to daylight under CIE Overcast sky

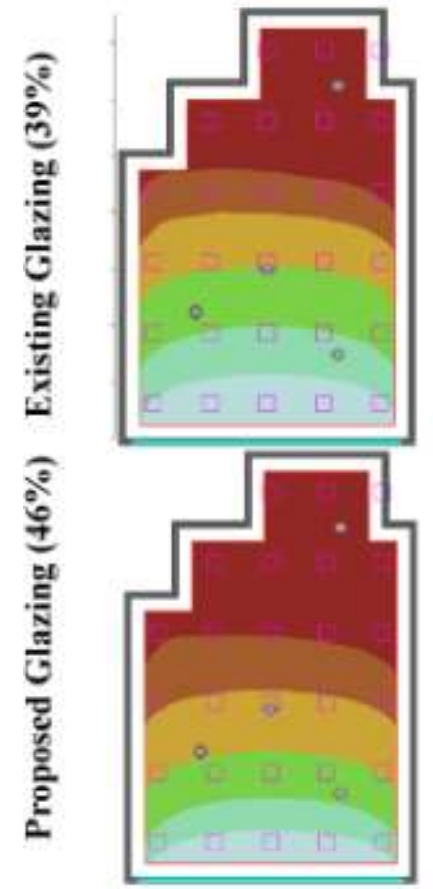

a) 11:00AM,23 June
For CIE Clear Sky
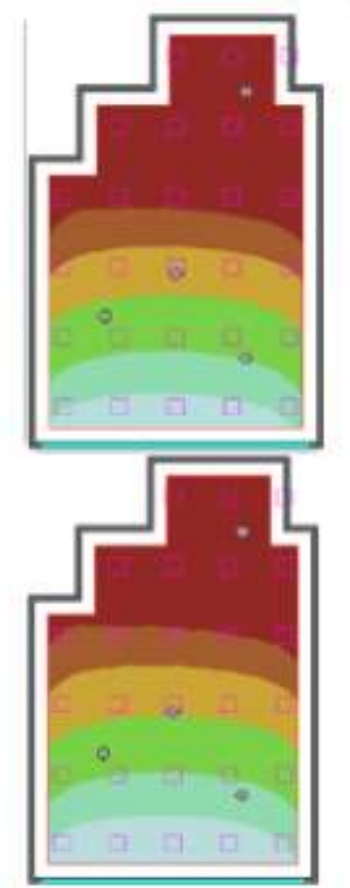

b) 11:00AM,22 Dec
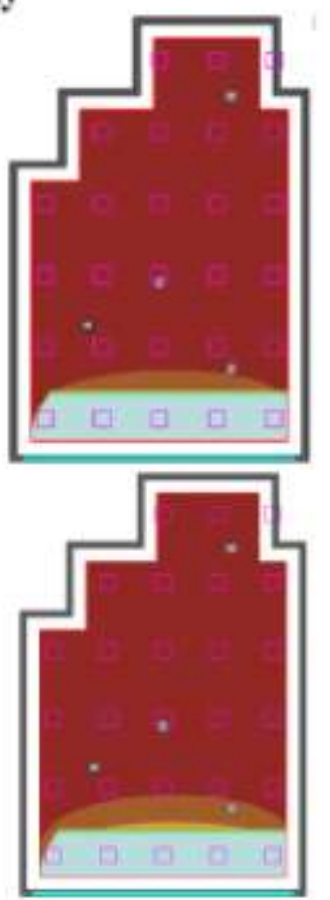

c) 03:00PM,23 June
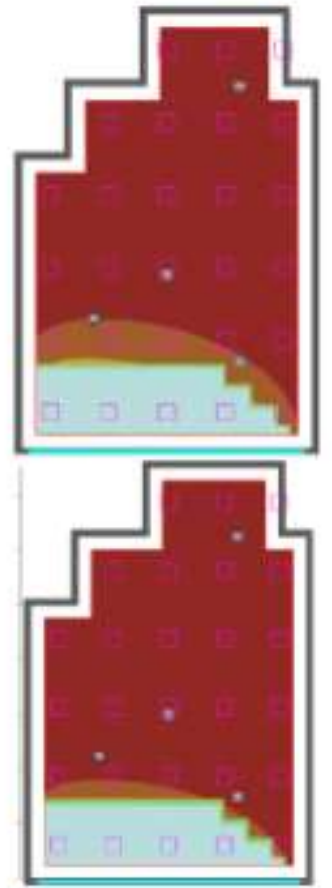

d) 03:00PM,22 Dec
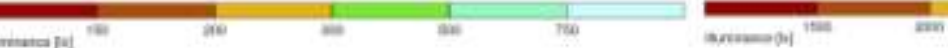

$\sin x$

Figure 6. Illuminance levels in the office interior due to daylight under CIE Clear sky 
Reducing the wattage of lighting system represents only one part of the energy saving opportunity; other part is to minimize the use of those loads using right control system. This involves the application of occupancy sensing, automatic switching and dimming according to the availability of daylight. It is planned to implement daylight dependent light control system in the building for maximum daylight harvesting for interior illumination. Daylight harvesting systems are typically designed to maintain a minimum recommended light level. All daylight harvesting systems use a light level sensor to detect the prevailing light level. The signal from the sensor is interpreted by a lighting control module in the electric lighting system, and the electric lighting can be reduced, if appropriate. If the electric lighting is dimmable, then the artificial lighting may be continually reduced in proportion to the amount of daylight available. If the electric lighting is on-off only, then the electric lighting must remain on at full output until daylight can meet the entire recommended light level for the space.

\subsection{Proposed System}

The suggested architectural lay-in LED luminaire [18] shown in Figure 2 is an amazing combination of technical innovations, including breakthroughs in optical design, electronics design, mechanical design, and thermal management. The LEDs used in the suggested LED luminaire are ENERGY STAR qualified products. The core of the innovation is a new way to generate white light with LEDs. The design of traditional lay-in fixtures is limited by the use of fluorescent technology. Lighting requirements dictate the use of multiple large sources that are challenging to accommodate, restricting aesthetic possibilities. LED technology does not have these constraints; enabling products that is suggested to break the norms of lay-in fixture design and create fresh and contemporary solutions. Many fluorescent luminaires are very bright when viewed from a distance. This creates a busy appearance with scores of bright squares scattered across the ceiling. In the suggested luminaire, lens is recessed into the lower reflector to provide mechanical shielding and a soft, low brightness appearance when viewed at a distance - blending into the ceiling plane.

Suggested LED luminaire has a luminous efficacy of 73 lumens/watt compared to the existing Fluorescent luminaire which has a similar luminous efficacy of 72 lumens/watt. But LED luminaire has a longer life of 50,000 hours compared to 20,000 hours of Fluorescent luminaire. Hence in a life cycle of 25 years one need not have to replace LED luminaire compared to more than two times replacement of a Fluorescent luminaire.

From RELUX simulations one can see lot of positives for the suggested LED luminaire. It can be observed from the Table 2 that annual energy costs have come down from Rs 160,000 to Rs
120,000 a saving of $22 \%$ for 2088 hours of operation. Further with daylight harvesting the annual operating costs will be Rs 4,900 thereby saving Rs 115,100.

The next section discusses in detail the quality and life cycle cost comparisons for the two schemes.

\subsection{Life Cycle Cost and Quality Analysis}

In this section we will compare the two schemes based on Uniformity of Illuminance, Luminance Distributions, Glare and Life Cycle Costs.

\subsubsection{Uniformity of Illuminance}

Uniformity of lighting depends on the type and arrangement of the luminaires, on the geometry of the lighting system and on the type of surfaces being illuminated. Local uniformity of lighting is important for comfort and visual performance. Uneven luminance and illuminance can lead to camouflage zones in which there is inadequate contrast between objects and their surroundings, and because our eyes have to adapt and re-adapt often, they tire quickly.IS-3646 [17] recommend that, the ratio of illumination level between the task area and the background should be less than 3. This means that ratio of minimum illuminance to maximum illuminance on the work plane should be around 0.67 or more. In practice it is too tight to meet exact ratios. As seen from Table 2, with LED luminaire a uniformity ratio of 0.64 is achieved compared to 0.5 in the case of Fluorescent luminaires.

It can be seen from Figure 3 the spread of illuminance and luminance in one of the office floors of building for both types of luminaires. Also one can see an important fact from Table 2, the total luminous flux from all lamps for all floors of the building has come down from 926 Kilo lumens for Fluorescent luminaires to 719 Kilo lumens for LED luminaires an improvement of nearly 20\%. This suggests that LED luminaires are efficient enough to spread the luminous flux more evenly on the work plane and improve the quality of illuminance than compared to Fluorescent luminaires. In case of Fluorescent luminaires there is no uniformity in luminance distributions compared to LED luminaires.

\subsubsection{Glare}

The Uniform Glare Rating (UGR) is an approximate model that expresses the chance of direct glare by luminaires. The higher this figure, the greater the chance of glare.UGR values are usually expressed in steps of 3 . For example a typical office environment requires a UGR of 19 or less [17].

As seen from RELUX simulations in Figure 7 both the luminaires achieve a UGR of around 19 for four critical observer positions, guaranteeing a glare free working environment. 

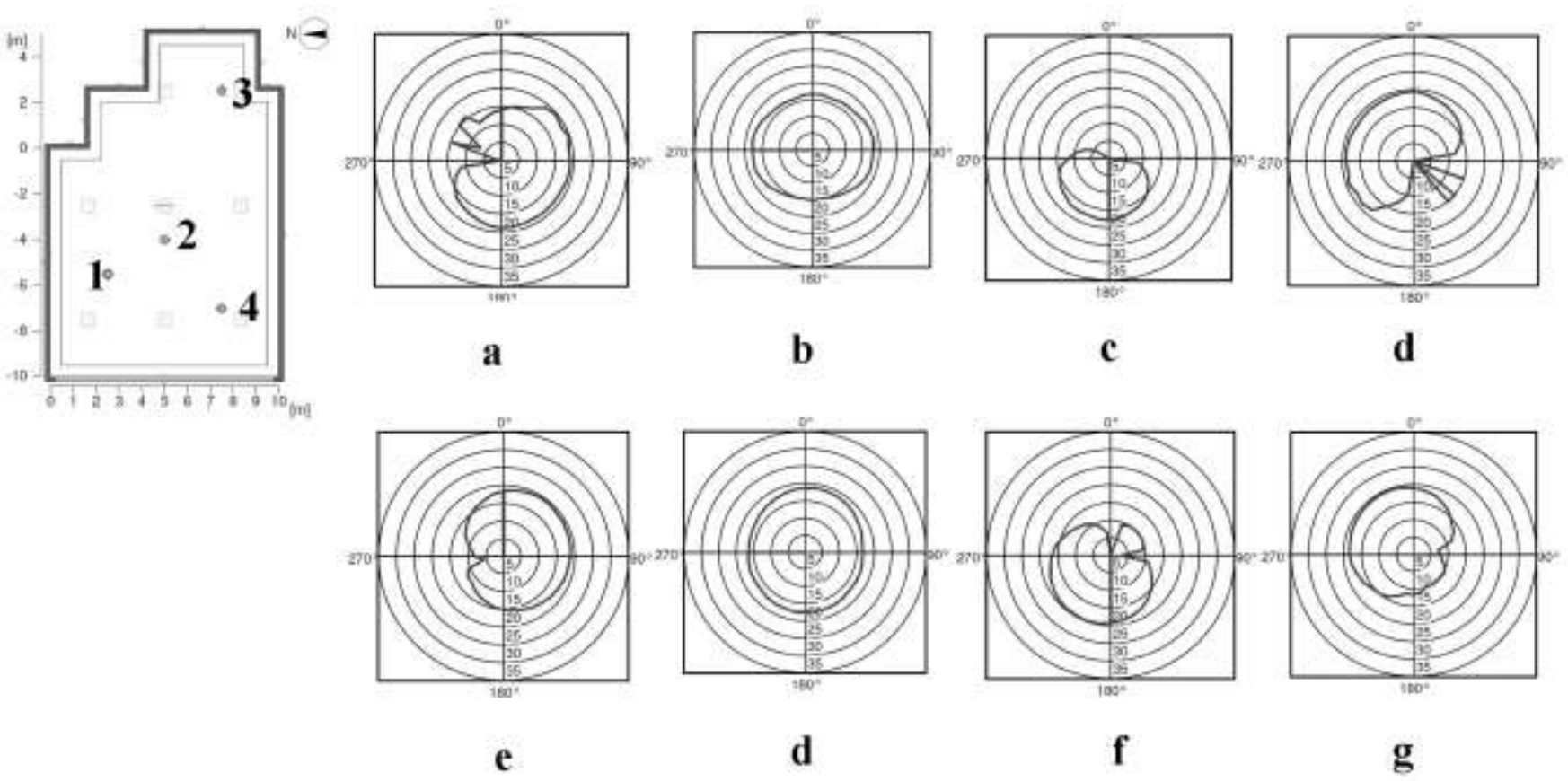

GLARE RATING (UGR) CALCULATIONS

Figure 7. Glare Rating (UGR) for four observer positions - Fluorescent luminaire (a) to (d) and LED luminaire (e) to (g) for positions 1, 2, 3 and 4 respectively

\subsubsection{Life Cycle Cost Analysis}

To evaluate the economic impacts of the LED lighting alternative, an analysis was done for 25-year life cycle. As this was a new construction project, the LED lighting costs were compared to the costs of purchasing the Fluorescent fixtures. The LED light fixtures cost Rs. 4,328,100 compared to Rs. 1,038,800 of the Fluorescent fixtures almost four times expensive.

The Fluorescent fixtures consumed significantly more energy than the LED fixtures. Each Fluorescent fixture consumes $120 \mathrm{~W}$ for the lamps plus $10 \mathrm{~W}$ for the ballast. The LED fixtures each consume $52 \mathrm{~W}$. The total lighting load with Fluorescent fixtures is $12.74 \mathrm{KW}$ as compared to $9.82 \mathrm{KW}$ for LED fixtures. Taking a power tariff of Rs 6 per KWH and assuming around 6 to $8 \%$ rise in power tariffs every year it can be seen from Table 3 an overall savings of $22 \%$ on Life Cycle Energy Costs with LED fixtures as compared to Fluorescent fixtures.

The LED fixtures offer extremely long lamp life - 50,000 hours of use before considering replacement. A lifetime of 50,000 hours represents 24 years assuming 8 hour-a-day operation. After 50,000 hours, the lights are not out. Instead, they simply have reduced light output $-70 \%$ of the original output. After 50,000 hours, or 24 years, the LED modules in the fixtures can be replaced. Fluorescent fixtures have a life of 20,000 hours; they have to be replaced more than twice during 25 years life cycle. There is an extra cost of Rs. 5,177,194 for replacement in comparison with LED fixtures. The total cost of owning an LED lighting system is much cheaper compared to Fluorescent lighting system as Life Cycle Cost per fixture per year is less for LED fixtures than Fluorescent fixtures.
Table 3 Life Cycle Cost Analysis

\begin{tabular}{|l|r|r|}
\hline Details & \multicolumn{1}{|l|}{$\begin{array}{l}\text { Fluorescent } \\
\text { Luminaire }\end{array}$} & \multicolumn{1}{l|}{$\begin{array}{l}\text { LED } \\
\text { Luminaire }\end{array}$} \\
\hline Luminaire Cost (Including Lamps) & Rs 10,600 & Rs 22,900 \\
\hline Lamp Life in hours & 20,000 & 50,000 \\
\hline Annual Energy Costs & Rs. 1,038,800 & Rs. 4,328,100 \\
\hline Lighting Equipment Cost & Rs 9,800 & Rs 18,900 \\
\hline Lighting Installation Cost & Rs 1,415,556 & Rs 1,092,000 \\
\hline Wiring \& Service/Distribution Cost & Rs. 10,104,978 & Rs. 7,795,268 \\
\hline $\begin{array}{l}\text { Life Cycle Energy Cost for 25 } \\
\text { years }\end{array}$ & Rs. 620,455 & Rs. 1,196,592 \\
\hline $\begin{array}{l}\text { Life Cycle Cleaning Costs for 25 } \\
\text { years }\end{array}$ & Rs. 18,366,782 & Rs. 14,430,860 \\
\hline $\begin{array}{l}\text { Life Cycle Replacement Costs for } \\
\text { 25 years }\end{array}$ & Rs. 7,497 & Rs. 3,054 \\
\hline Total Life Cycle cost & &
\end{tabular}

This analysis can be considered a conservative one in that energy costs are likely to increase much faster than the 6 to $8 \%$ assumed here. Furthermore, capabilities of the LED light fixtures offer the option to use occupancy control to further reduce the energy consumption and extend the service life of the fixtures.

\section{DAYLIGHT ANALYSIS}

As analysed in Section 3.1 if daylight harvesting is done we can save nearly $96 \%$ of the energy costs. However in practice not all portions of the office interior will receive desired amount of 
daylight due to building orientation and room dimensions. Therefore there is a requirement of supplementary artificial lighting during day hours. This section analyses the daylight scheme with existing and proposed glazing type and its impact on heat gain and air conditioner loads.

In order to gain more insight about the indoor day lighting performance, one of the office floors was simulated using RELUX. The simulations where done for two days 23 June and 22 December under both CIE Overcast Sky and CIE Clear Sky for 10AM, 11AM, 12PM,3PM,4PM and 5PM.The times where considered based on the maximum occupancies for similar offices in India. As seen from computer simulation results in Figures 5, 6 and 8 and it can be observed that for the office building even during daytime there is requirement of supplementary illumination from artificial light sources. Places far away from windows have to be provided with artificial lighting even during clear sky conditions throughout the day. In a side-lit office, the uniformity of the day lighting will depend mainly on the dimensions of the rooms and the surface reflectance. If a multi-storey building is to be lit by daylight, there will be limits on its overall plan depth. If length of the office is too long comparing with the office width and height, then the rear half of the room tends to look gloomy and supplementary electric lighting will be required. This is proved with RELUX simulations, at nearly $4 \mathrm{~m}$ from the window the illuminance drops to less than 500 lux under Overcast Sky and at $7 \mathrm{~m}$ under Clear Sky. As seen from the results there is no requirement of artificial lighting for the areas which are $4 \mathrm{~m}$ to $7 \mathrm{~m}$ away from the window hence there could be significant saving in energy in these areas. Further savings in cooling energy and heat rejection could be obtained due to less sensible heat gains generated by artificial lighting fittings.

The existing structural glazing is provided by Saint Gobain Glass type SGG Antelio Plus Blue Ray [15] it is a double glazed unit with a relative heat gain of $U$ value of $2.8 \mathrm{w} / \mathrm{sqmK}$ and light transmission of $39 \%$. Mumbai requires cooling throughout the year. Hence it is advisable to go for Low-Solar-Gain Low-E Glass for glazing. Low-E glass provides a higher level of visible light transmission for a given amount of solar heat reduction. Variants on low-solar-gain low-E coatings have also been developed which may appear slightly tinted. This type of low-E product reduces heat loss in winter and substantially reduces solar heat gain both in winter and in summer. Thus, low-solargain low-E glazing is ideal for buildings located in coolingdominated climates. The best possible option is to go for Saint Gobain Glass type SGG Antelio Plus Emerald Glaze a double glazed unit with low-e coating and a light transmittance of $47 \%$ and relative heat gain of $U$ value of $1.77 \mathrm{w} / \mathrm{sqmK}$. There by improving the light transmittance by near $22 \%$ and reducing heat gain thus reducing cooling requirement by $37 \%$. Further the ratio between Solar Heat Gain Coefficient and Visual Transmittance is called the light-to-solar gain ratio (LSG.) This provides a gauge of the relative efficiency of different glass types in transmitting daylight while blocking heat gains. The higher the ratio number the brighter the room is without adding excessive amounts of heat. The LSG ratio is higher in case of proposed glazing type at 1.4 compared to 0.91 in case of existing glazing type.
With RELUX simulations in Figures 5 and 6 we can see that proposed glazing SGG Antelio Plus Emerald Glaze [15] allows $22 \%$ more day lighting in the office floor compared to the existing glazing. Proposed glazing is better for solar heat control and reducing cooling energy costs. Proposed Glazing costs nearly $15 \%$ more than existing glazing. However proposed glazing is a larger investment initially but will pay for itself by reducing heating and cooling costs.

The energy and life cycle cost analysis was done for existing and proposed glazing and the results are summarized in Table 4. It can be seen from the Table 4 that the air conditioner requirement to meet solar heat Gain through glazing has come down from 1.5 tonnes with existing glazing to 1 tonne with proposed glazing. This resulted in an annual saving of $20 \%$ on energy costs. As seen Table 4 from the cost of owning the proposed glazing is much cheaper compared to existing glazing over a period of 25 years life cycle.

\section{DAYLIGHT HARVESTING}

To take full advantage of daylight integration, buildings should have automated controls that either turn off or dim artificial lighting in response to the available daylight in the space. This is traditionally called "daylight harvesting". Daylight harvesting starts with lighting controls that are flexible enough to accommodate the changing requirements of occupants in a space. Control flexibility improves lighting energy performance by establishing a base level of illumination and then encouraging the use of only those lights that are needed for the activity at hand. It also increases occupant satisfaction through user control. On the other hand, while some occupants are quite conscientious about manually "tuning" lighting for their needs, including turning off or dimming lighting when not needed, automatic systems tend to result in greater energy savings over the long run. They should always be supplemented with manual override to accommodate individual differences.

Automated systems usually include optical sensors (photocells) that read ambient light levels to both maintain a base level of illumination, by using as much free natural daylight as possible, and occupancy sensors to shut lights off when spaces are unoccupied. Using an integrated occupancy and daylight dimming sensor will not only guarantee the correct lighting level in a room at any time but will also make sure that lights are turned off when a room is not in use. Daylight harvesting control strategies can be established so that the controls can be operated manually by users or automatically using photo sensors. Since automatic strategies do not depend on human initiative, they are generally more effective at saving energy.

\subsection{Combined Occupancy \& Daylight Dimming Sensors}

Occupancy Sensors are extremely sensitive PIR Motion Sensors. They can detect much finer movements and also are a lot smaller. Although simple in concept Occupancy Sensing is probably the single most effective energy saving strategy. For energy saving lighting a full Office Automation system is not necessary. Decentralise, reliable lighting controls often do a much better job (less configuration, less maintenance). Therefore individual 
daylight dimming is suggested for each of the LED luminaire

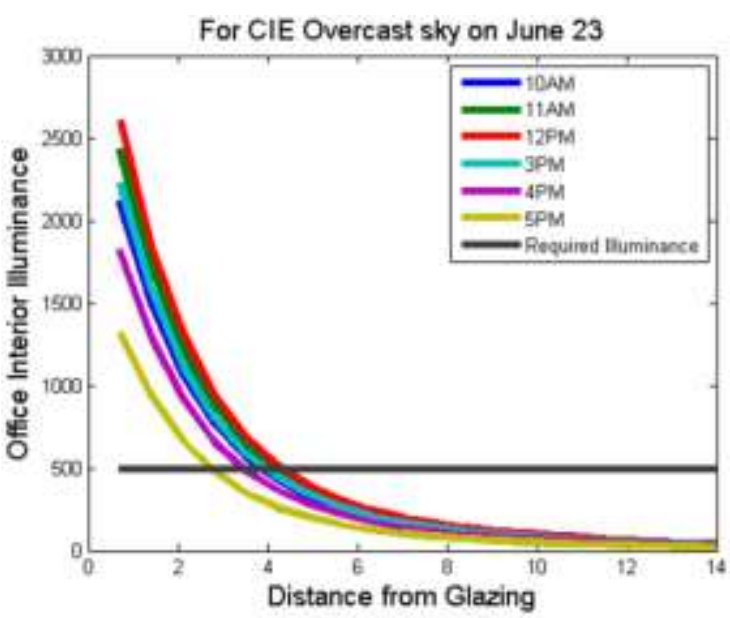

For CIE Overcast sky on December 22

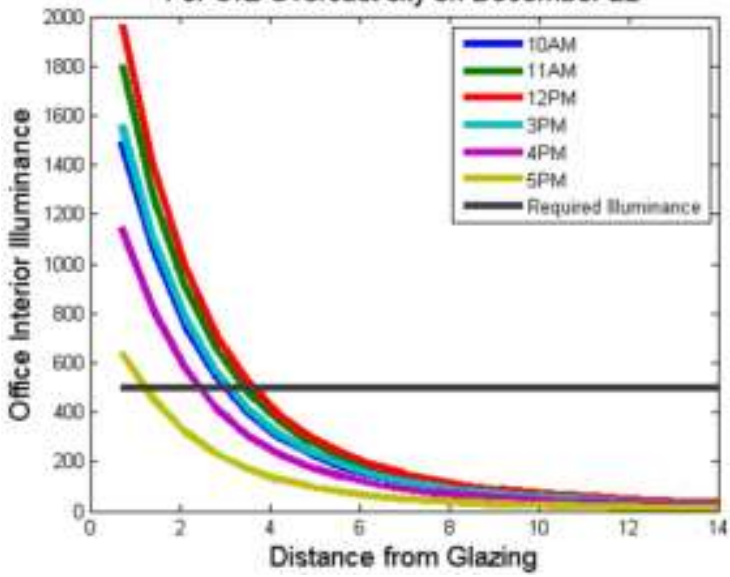

with occupancy \& daylight sensor built within the fixture.

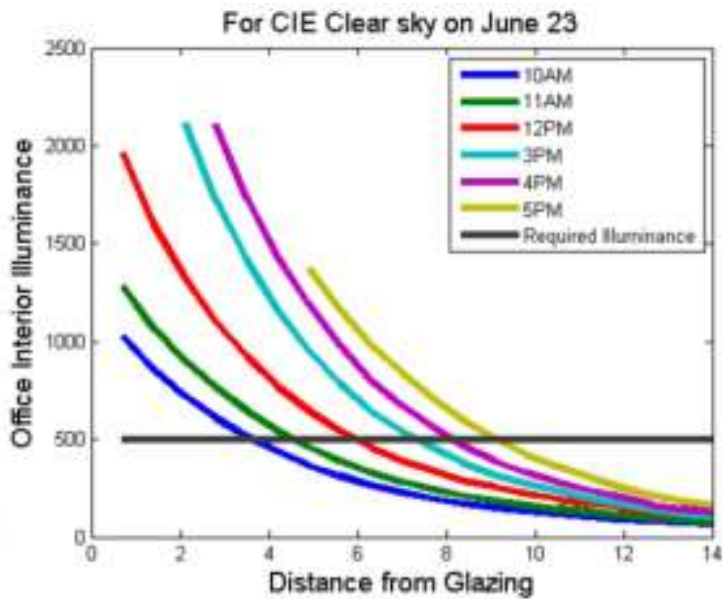

For CIE Clear sky on December 22

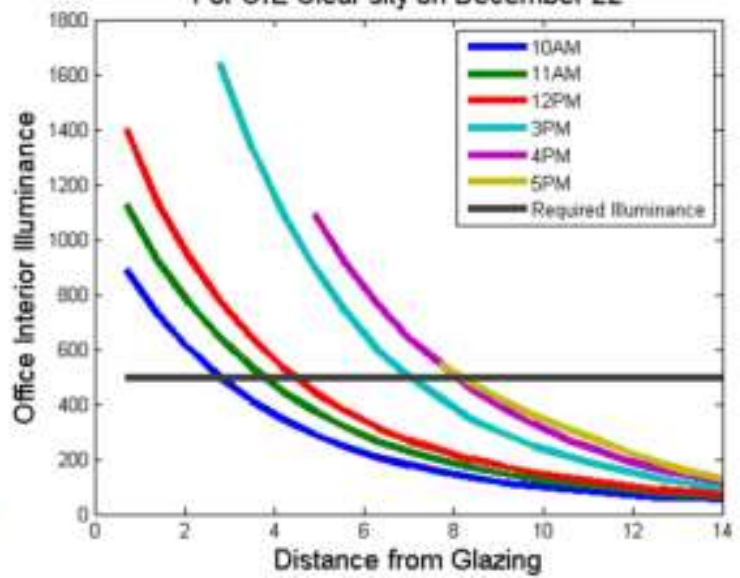

Figure 8. Interior Illuminance levels in the office floors during different hours of the day for dates June 23 and December 22

Table 4 Energy and Life Cycle Cost Analysis of Structural Glazing

\begin{tabular}{|c|c|c|}
\hline & Existing Glazing & Proposed Glazing \\
\hline Type & $\begin{array}{l}\text { SGG Antelio Plus Blue } \\
\text { Ray }\end{array}$ & $\begin{array}{llll}\text { SGG Antelio Plus } & \text { Emerald } \\
\text { Glaze } & & & \end{array}$ \\
\hline Light Transmission & $39 \%$ & $47 \%$ \\
\hline U Value $\left(\mathrm{W} / \mathrm{m}^{2} \mathrm{~K}\right)$ & 2.8 & 1.77 \\
\hline Solar Factor & 0.37 & 0.31 \\
\hline Shading Co-efficient & 0.43 & 0.35 \\
\hline Tonnage Requirement of Air conditioner to meet Solar Heat Gain through Glazing & 1.5 & 1 \\
\hline Annual Energy Costs & Rs. 18,792 & Rs. 15,284 \\
\hline Initial Cost of Glazing & Rs. $465,500.00$ & Rs. $558,600.00$ \\
\hline Cost of Air-conditioning to meet Solar Heat Gain through Glazing & Rs. $20,000.00$ & Rs. $16,000.00$ \\
\hline Life Cycle Glazing Cleaning and Maintenance Cost & Rs. 781,482 & Rs. 781,482 \\
\hline Life Cycle Energy Costs for 25 years & Rs. $1,223,802$ & Rs. 995,359 \\
\hline Total Life Cycle Cost & Rs. $2,486,784$ & Rs. $2,355,441$ \\
\hline Life Cycle Cost per Sq.m of Glazing per year & Rs. 2,991 & Rs. 2,833 \\
\hline
\end{tabular}




\subsubsection{Individual Daylight Dimming - One Sensor per fitting}

Integrated Occupancy and Daylight Harvesting Sensor suggested [19] for the project is shown in Figure 9. These sensors are specifically designed for very demanding applications, e.g. persons working concentrated at a PC where the only motion is typing on a keyboard. When there is no daylight, this sensor work just like the simpler On/Off sensors. However, as soon as a certain amount of daylight is available, the artificial light will be reduced gradually.

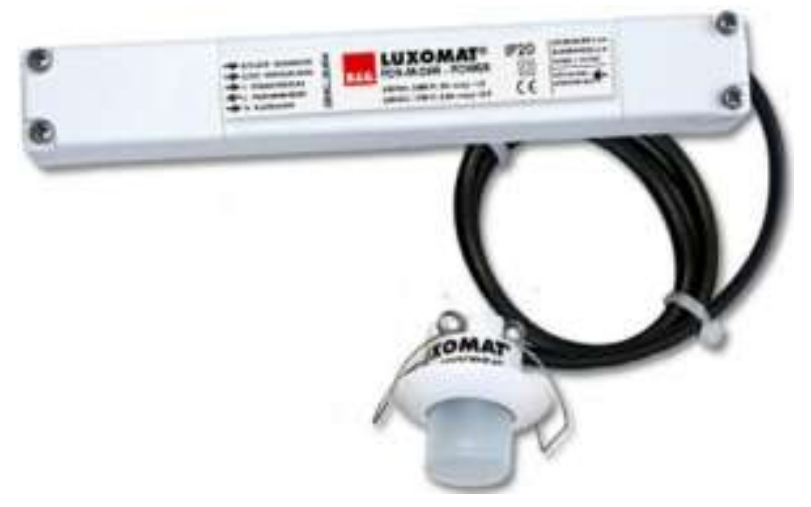

Figure 9. Integrated occupancy and daylight harvesting sensor suggested for the project

\subsubsection{Computer Simulations for Sensor calculations}

The Figure 10 shows the detection range of one sensor when placed at the centre of the office building. The size of this observation area can be adjusted by pulling out the shading ring around the sensor lens. The sensor has detection capabilities in $360^{\circ}$, it has a circular detection range for seated persons at $2.50 \mathrm{~m}$, tangential at $10 \mathrm{~m}$ and radial at $6 \mathrm{~m}$.

Using RELUX software, the sensor layouts where fixed and the detection ranges of all the sensors put together where simulated as shown in Figure 19. One can see from the results that the sensor's presence detection range covers almost entire office floor there by effectively detecting occupancy and light levels for energy efficient daylight harvesting.

\subsection{Energy Cost Analysis}

Using RELUX-Energy, energy evaluation was done for the office floor using EN15193 standards. The software separates the day lit section $\left(75 \mathrm{~m}^{2}\right)$ and artificial light sections $\left(65 \mathrm{~m}^{2}\right)$ in the office floor. The energy evaluation gives details of energy consumption profiles for different sections within the office floor for different daylight control schemes. As we can see from the Table 5 and Figure 11 which summarizes the energy consumptions under different control schemes for different months of the year. Four different schemes where considered, one with only LED lighting and no occupancy detection or daylight harvesting, three of the daylight harvesting schemes where considered with different control schemes like presence control in daylight section of the office floor using Manual On/Off and Manual On \& Auto/Off. Similarly for presence control in artificial lighting section using Manual On/Off and Manual On \& Auto/Off.

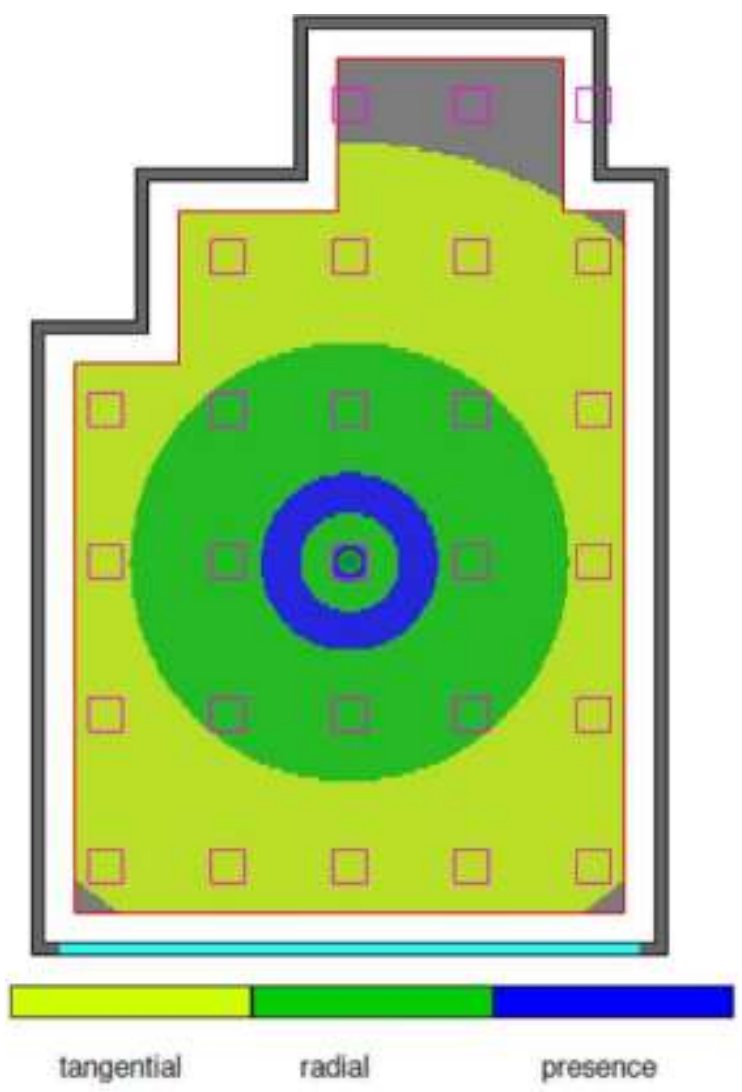

Figure 10. Detection range of selected sensor as simulated in RELUX software

In comparison to Fluorescent lighting scheme without daylight harvesting and lighting controls in Daylight Harvesting Scheme 3, which incorporates Combined Occupancy \& Daylight Dimming Sensors, we can be seen that maximum energy saving up to $70 \%$ can be achieved over the Fluorescent Scheme. Further this scheme also reduces the Life Cycle Cost per fixture per year from Rs 3,054 to Rs 2,095 a saving of further 33\% as summarised by Table 6. Compared to the existing Fluorescent scheme nearly $80 \%$ can be saved in energy costs and Life Cycle Cost per fixture per year. 


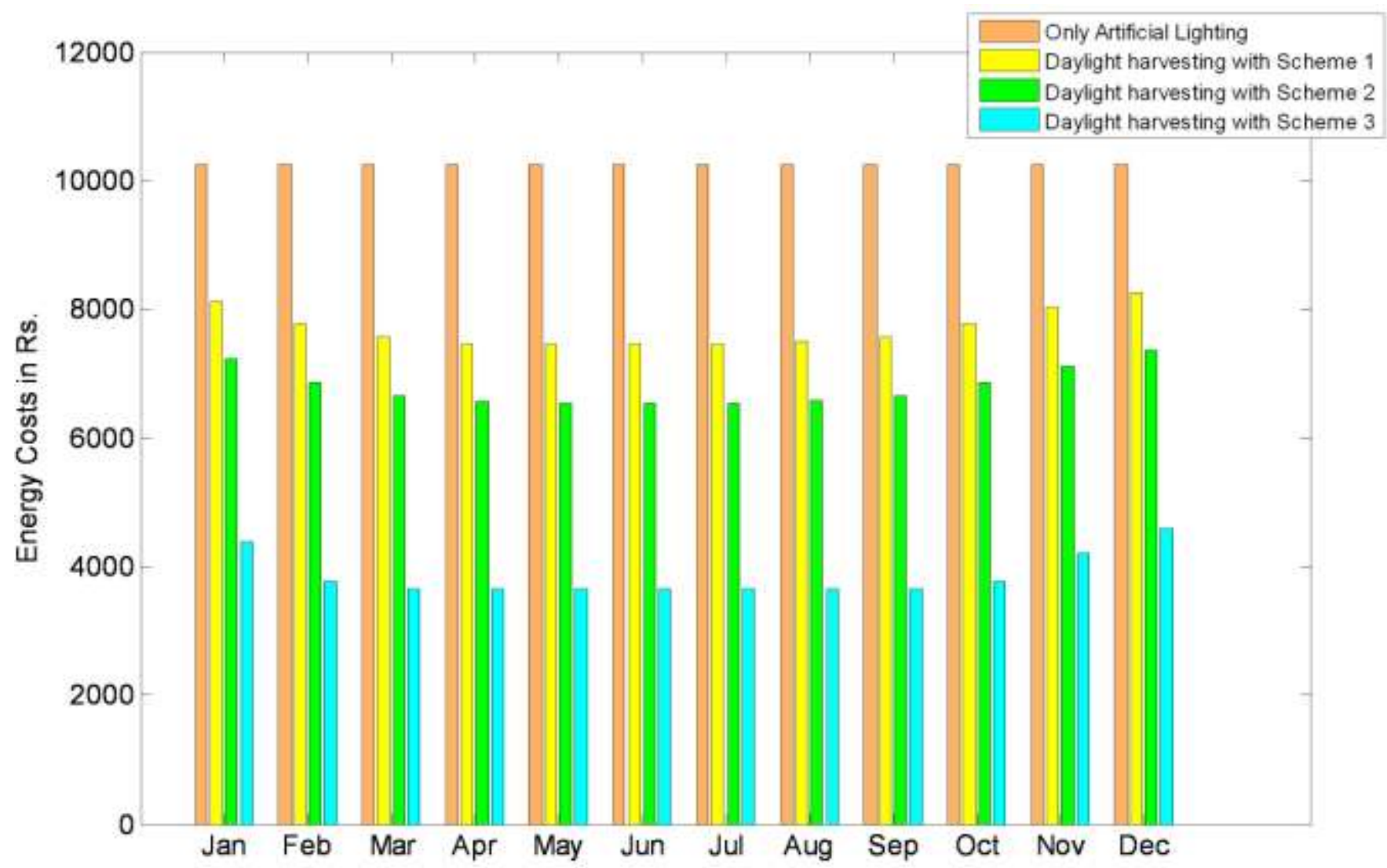

Figure 11. Energy costs with different lighting schemes

Table 5 Energy cost comparison with different lighting schemes

\begin{tabular}{|c|c|c|c|c|}
\hline & Only LED Lighting & $\begin{array}{ll}\text { Daylight } & \text { Harvesting } \\
\text { Scheme 1 } & \end{array}$ & $\begin{array}{ll}\text { Daylight } & \text { Harvesting } \\
\text { Scheme } 2 & \end{array}$ & $\begin{array}{l}\text { Daylight } \text { Harvesting } \\
\text { Scheme } 3\end{array}$ \\
\hline \multicolumn{5}{|l|}{ Daylight Section $\left(75 \mathrm{~m}^{2}\right)$} \\
\hline Presence Control & & Manual & Manual & Manual / Auto Off \\
\hline Daylight Depending Control System & & Manual & Manual & $\begin{array}{l}\text { Automatic, } \\
\text { Daylight } \\
\text { dependent }\end{array}$ \\
\hline $\begin{array}{l}\text { Percentage of Total Energy } \\
\text { Consumption in Day lit Section }\end{array}$ & & $41 \%$ & $46 \%$ & $5 \%$ \\
\hline \multicolumn{5}{|l|}{ Artificial Light Section $\left(65 \mathrm{~m}^{2}\right)$} \\
\hline Presence Control & & Manual & Manual /Auto Off & Manual/Auto Off \\
\hline $\begin{array}{l}\text { Percentage of Total Energy } \\
\text { Consumption in Artificial lighting } \\
\text { section }\end{array}$ & & $59 \%$ & $54 \%$ & $95 \%$ \\
\hline Parasitic Power in Watts & & 6538 & 6538 & 6538 \\
\hline Annual Energy Costs & Rs 123,126 & Rs 92,370 & Rs 81,426 & Rs 46,218 \\
\hline
\end{tabular}


Table 6 Life Cycle Cost Comparison for LED Lighting and Integrated Daylight \& LED Lighting with Daylight dependent lighting control system

\begin{tabular}{|l|r|r|}
\hline Illumination Provided by & \multicolumn{1}{|l|}{$\begin{array}{l}\text { Only LED } \\
\text { lighting }\end{array}$} & $\begin{array}{l}\text { Daylight } \\
\text { Harvesting }\end{array}$ \\
\hline Annual Energy Costs & Rs. 123,126 & Rs 46,218 \\
\hline $\begin{array}{l}\text { Additional Costs on Lighting control } \\
\text { system (Includes occupancy sensors, } \\
\text { control circuitry and installation costs }\end{array}$ & & Rs 378,000 \\
\hline Life Cycle Energy Cost for 25 years & Rs 7,795,268 & Rs 2,885,311 \\
\hline $\begin{array}{l}\text { Total Life Cycle Cost for 25 years } \\
\text { Life Cycle Cost per fixture per year }\end{array}$ & Rs. 9,898,903 3,054 & Rs 2,095 \\
\hline $\begin{array}{l}\text { Life Cycle Cost per } m^{2} \text { of total floor } \\
\text { area per year }\end{array}$ & Rs 610 & Rs 426 \\
\hline
\end{tabular}

\section{CONCLUSION}

Faced with the skyrocketing cost of energy and environmental concerns, builders, architects and lighting specialists are increasingly turning to day lighting as a primary source of illumination in mainstream construction. Day lighting will provide tremendous operating cost reductions if properly integrated with an electrical lighting control system. For successful daylight integration, certain principles need to be followed in terms of optimum building placement: the location, design and selection of materials for fenestration (windows, skylights, etc.) and electrical lighting design. In general, the earlier in the design process of new buildings that day lighting issues are addressed, the more successful the daylight harvesting project will be. The designer should evaluate if the quality, distribution or amount of day lighting could be improved during pre-design and schematic design phases. Simulation software like RELUX can be used to evaluate the full integration of daylight harvesting and electric lighting controls with buildings characteristics.

In summary,

1) An in-depth analysis has to be performed on the daylight harvesting potential of a building at the earliest possible stage before construction.

2) Total building automated lighting controls should be used to maximize daylight harvesting benefits and energy savings.

3) Energy efficient lighting equipment such as LED fixtures can be used to help cut lighting operational costs

\section{REFERENCES}

[1]. $\mathrm{Wu}$ MKT, Lam KK. Office lighting retrofit using T5 fluorescent lamps and electronic ballasts. Hong Kong Inst Eng Trans 2003;10:55-60.

[2]. Öztürk LD. Determination of energy losses in lighting in terms of good vision efficiency. Archit Sci Rev 2008;51(1):39-47
[3]. Kurian CP, Aithal RS, Bhat J, George VI. Robust control and optimization of energy consumption in daylight-artificial light integrated schemes. Light Res Technol 2008;40(1):724.

[4]. Doulos L, Tsangrassoulis A, Topalis F. Quantifying energy savings in daylight responsive systems: the role of dimming electronic. Energy Build 2008;40(1):36-50.

[5]. Loutzenhiser PG, Maxwell GM, Manz H. An empirical validation of the daylighting algorithms and associated interactions in building simulation programs using various shading devices and windows. Energy - Int J 2007;32(10):1855-70.

[6]. Chel A, Tiwari GN, Chandra A. A model for estimation of daylight factor for skylight: an experimental validation using pyramid shape skylight over vault roof mud-house in New Delhi (India). Appl Energy 2009;86(11):2507-19.

[7]. Ruck NC. International Energy Agency's solar heating and cooling task 31 - daylighting buildings in the 21st Century. Energy Build 2006;38(7):718-20.

[8]. To DWT, Leung KS, Chung TM, Leung CS. Potential energy saving for a side-lit room using daylight-linked fluorescent lamp installations. Light Res Technol 2000; 34(2):121-33.

[9]. Li DHW, Lam JC. Evaluation of lighting performance in office buildings with daylighting controls. Energy Build 2001;33(8):793-803.

[10].Li DHW, Lam TNT, Wong SL. Lighting and energy performance for an office using high frequency dimming controls. Energy Convers Manage 2006;47(9-10):1133-45.

[11].Li DHW, Lam TNT, Wong SL, Tsang EKW. Lighting and cooling energy consumption in an open plan office using solar film coating. Energy - Int J 2008;33(8):1288-97.

[12].Li DHW, Lam TNT, Chan WWH, Mak AHL. Energy and cost analysis of semi-transparent photovoltaic in office building applications. Appl Energy 2009;86(5):722-9

[13]. Ward GL, Shakespeare R. Rendering with RADIANCE. The art and science of lighting visualization. Los Altos, CA: Morgan Kaufman; 1998.

[14].CIBSE. Applications manual: window design. Chartered Institution of Building Services Engineers, London; 1987.

[15]. Saint Gobain India. 2010. Reflective Glass with Nano Coating - SGG ANTELIO PLUS. http://in.saint-gobainglass.com/

[16].Philips. 2010. DPA2G9LP3FT 3 Feet 9 Cell 2x2 3 Lamp TT5 Parabolic. http://www.lightolier.com/

[17].Bureau of Indian Standards. Code of practice for interior illumination (IS 3646). 1992

[18]. Cree Lighting. 2010. LR24-38SKA35 Architectural Lay-ins. http://www.creelighting.com/

[19].Luxomat. 2010

PD9-M-DIM-GH-FC http://www.luxomat.com/ 